\title{
Time-specificity of the future of performance
}

\author{
Nik Wakefield
}

\section{Art (?) Life}

The future of performance consists of the complexity of an unknown guaranteed rather than the simplicity of a success or failure. This article offers a critique of failure in contemporary performance theory through the name of change of Janez Janša, a work of performance practice as research entitled Three and the philosopher Henri Bergson's writings on disorder. If one aspect of the questions of the relationship between art and life has to do with how much freedom is possible in one or the other, perhaps the future helps, because in the future there can be no difference between art and life. Both the futures of life and the futures of art are unknowable and guaranteed to the same degree. Underpinning this article is an exploration of how best to formulate the relationship between art and life, manifested in fig. 1-A Map of Art (?) Life.

\section{Successful Failure}

In her book Performance Theatre and the Poetics of Failure, Sara Jane Bailes writes that as a "failure is inclusive, permissive even [...] [I]t can lead to unanticipated effects."1 Failure shows itself to be a useful tool for arts practices that are concerned with political critique because failure aims to show how traditional methods of representation become competitive and exclusive the more they value virtuosity. Democracy relies on representation, but contemporary politics are participated in through disenchantment and disillusionment. Representation comes to be seen as a corruptive agent in politics, art and philosophy. Failure shows the attempt and the breakdown. It shows awareness of what is being asked for and the gesture of refusal.

Failure critiques the notion of progress as being purely positive. Bailes defines failure's specific temporality. "The relationship between labour and failure - the intellectual and physical operations that the failed condition creates - becomes intriguing in terms of its material and metaphysical effects, and its orientation toward a/the future."2 Failure shows that you do not have to succeed to continue, it defies the pressure to perform, it objects to entering into mechanical circulations of capital in the economy of experience. It also creates conditions for a future in which new positions have to be created. "The aspect of

\footnotetext{
${ }^{1}$ Sara Jane Bailes, Performance Theatre and the Poetics of Failure, London: Routledge, 2010, p. 2.

2 Ibid., p. 2.
} 
'hope' underpins my argument with its implications for the futurity of performance." 3 In Bailes' view, failure is positive and productive. Failure is enabling because it problematizes normativity. As an aesthetics strategy, failure operates correlatively to the political imperative to either work within or opt out of systems one finds too broken to fix.

In the 2014 book MISPerformance: Essays in Shifting Perspectives, editors Marin Blaževič and Lada Čale Feldman point to an interesting paradox in Bailes' framework of failure. "Failure turned into a constitutive element of a poetics presupposes a success ( $a$ successful failure) that conforms and confirms that very poetics. [...] What remains is failure that failed to fail[.]"4 If a poetics of failure can only mean that failure becomes an intended condition, failure becomes something other than a spontaneous emergence of difficulty and instead becomes a composable element. If the first part of the quote reveals a complex appropriation of failure that transforms it into an aesthetics strategy, the second part of the quote aims to reclaim failure as it was, an actuality that is now a virtuality. It becomes possible to speak of imposed and composed failure as different forms.

If an action can be a failure or a success, it becomes necessary to locate the perspective from which the decision is made. The inclusion of intention into the framework of failure suggests not only that such failures are also successes, but also that a technique of perception is required in order to observe an action as a failure or a success, not to mention a successful failure or a failed failure and so on. In an act of collusion, the audience agrees to pretend that the action has set up a desired result, but has instead produced an alternative. The audience knows that the artist knew that the action would "fail". This is the success.

Another option is that a set up produces a result that was not intended by the artist and is not accepted by the agreeable audience as an acceptable failure. This option escapes recognition and fails because it does not offer the inclusive transcendent irony of the successful failure. This shares some of the functions involved in the absurd or pleasurable suspension of disbelief necessary to imagine that an invisible wall separates the auditorium from the raised stage.

One result of this analysis is that failure therefore returns representation to an art genre that is sometimes seen as a critique of illusion. And yet, this all perhaps goes too far because it suggests that an impenetrable boundary exists between success and failure. Bailes' book makes a much more sophisticated point, as do the contributors to Feldman

\footnotetext{
${ }^{3}$ Ibid., p. 12.

${ }^{4}$ Marin Blaževič \& Lada Čale Feldman (eds.), MISPerformance: Essays in Shifting Perspectives, Ljubljana: Maska, 2014, p. 18.
} 
and Blaževič's edited volume. Perhaps there is the possibility that there are always degrees of success and failure to an action, and that what was intended as a failure can in fact not succeed.

\section{Three}

I performed some experiments that explored the theatre as an environment in which to evolve in Three, a solo performance I made between 2013 and 2014. One of these had to do with the idea that failure requires success. These three photographs capture it (figs. 2, 3 and 4). It was a simple choreographic action with a microphone stand. It is laid down on its side in order to create a one-foot high barrier. I make two running attempts to jump over it, but cannot. Although the barrier is relatively low, those in the audience who know me well also know that my chronic inflammatory demyelinating neuropathy has caused me enough muscle weakness that I actually cannot jump. I rotate the stand so that it becomes a barrier between myself and the audience. To cross to the other side, I "realize" that while I cannot jump, I can still slide under the stand. It is a lot easier this way. It is less showy and less virtuosic. It is a failure to jump. Although in another way it is a success. I was able to cross the barrier, but had to find a solution that existed outside the parameters that the preceding action had set up, that of jumping over the stand. Here is the text that went along with this action:

Time to Fail

Time to be lazy

STAND up left

MIC lay down, attempt jump, rotate, slide under

I did it

MIC up left

To fail

I must succeed at failing

There is no failure

Failure is nothing

This is so political

The failure becomes a positive action, a success. To make sense of the text, in addition to the allusion to Mladen Stilinović and the appropriation of the language of Tino Seghal, the idea that failure is nothing is inspired not only by John Cage but also by the French philosopher Henri Bergson. 


\section{Disorder and Order}

In Creative Evolution, Bergson tells a story about looking for a book of poetry. ${ }^{5}$ He takes a book off a shelf, opens it to a random page and begins to read. He then returns the book to the shelf when he realizes that it is not poetry. Bergson's analysis is that the book cannot be made of a negative, a not poetry, and that it is instead prose. In Bergson's terminology, an intellectual effort causes the perception of the negative. The negative is a representation added to the existing positive. It appears to perfectly describe the same action as the identification of composed failure. For Bergson, order precedes disorder and fullness precedes emptiness, ${ }^{6}$ which I expressed in Three as "nothing does not exist".

Bergson returns to the idea in a later work. In Creative Evolution, Bergson makes the point about nothing being more than something in order to describe evolution as a positive and creative movement. Later, in The Creative Mind, his point is that imagining nothing preceding something makes the mistake of denying the force of duration, or suppressing duration to the spatiality of clock time. ${ }^{7}$ It assumes that the past does not interpenetrate with the present and projects the past into the future. It denies duration its radical inventive capability, which for Bergson is an undeniable function of experience. Order exists and differentiates through the force of duration. When Bergson describes evolution as the production of novelty, it does not mean that something is created from nothing. His point is that the future always arrives with more complexity than was imaginable and that the future is unpredictable. Crucially, it is unknowable in a different way than the disorder identified in an undesired order. Bergson, the politically active optimist, was convinced of a cosmos of positive immanence and committed to the political implications of indeterminism.

\section{Janez Janša}

The complexity of theory made possible by Bergson allows the framework of failure and success as a binary to be extended toward an indeterminism of positivity, where the future is unknown and guaranteed, which can be seen in the art practice of Janez Janša, Janez Janša and Janez Janša. Perhaps beyond success and failure is the identification of order through invention, which applies better to the name change, as Zdenka Badovinac explains. "Artistic projects serve as social laboratories of sorts, where some kind of new and not yet instrumental knowledge is being produced. Assessing the Janša project by the

\footnotetext{
${ }^{5}$ Henri Bergson, Creative Evolution, London: Macmillan, 1911, pg. 221.

${ }^{6}$ Ibid, pp. 273-286.

7 "The Possible and the Real" in Henri Bergson, The Creative Mind: An Introduction to Metaphysics, Seacacus: Citadel, 1946, pp. 91-106.
} 
success or failure of the provocation would be senseless since the provocation was just one of many strategies in the varied process of experimentation." ${ }^{8}$ Badovinac reveals that the creativity enabled through the name change operates beyond a binary between failure and success.

That the three artists succeeded in changing their names to Janez Janša is certainly not worthy of praise as artistic genius. The very simplicity of their partial sense of authorship bestows upon the surrounding social group the ability to create within the critical space they have opened. The name change made positive sense of the power of signification and enabled invention in a domain previously seen as limiting. Perhaps truly critical arts practices are those that announce the unimportance of either failure or success through their commitment to a task that involves a process of revealing order rather than disorder. The name change is one of these actions because it is positioned a step before success or failure.

By keeping the reason for changing the names personal and private, the work is uncontained. It does not require the intellectual effort to represent a negative. This makes the name change, like life and art, volatile and indetermined, able to mutate and evolve beyond recognition and representation and instead, surprisingly, towards a positivism of difference. This is the unknown guaranteed of the future, in which both life and art are the same, sharing in their mutual continuance. After all, now that seven years have passed since 2008, we can all breathe a sigh of relief knowing that the newspaper spat between the prime minister of Croatia and the Prime Minister of Slovenia did not escalate beyond the pages of Dnevnik.

Nik Wakefield is an American practitioner of art and theory based in London.

\section{Bibliography}

Badovinac, Zdenka. "What is the Importance of Being Janez?", in Name Readymade. Ljubljana: Moderna Galerija, 2008. Bailes, Sara Jane. Performance Theatre and the Poetics of Failure. London: Routledge, 2010.

Bergson, Henri. Creative Evolution. London: Macmillan, 1911.

--. The Creative Mind: An Introduction to Metaphysics. Secaucus: Citadel, 1946.

\footnotetext{
${ }^{8}$ Zdenka Badovinac, "What is the Importance of Being Janez?" in Name Readymade, Ljubljana: Moderna Galerija, 2008.
} 
Blažević, Marin and Feldman, Lada Čale (eds.), MISPerformance: Essays in Shifting Perspectives. Ljubljana: Maska, 2014.

\begin{abstract}
The future of performance consists of the complexity of an unknown guaranteed rather than the simplicity of a success or failure. This article offers a critique of failure in contemporary performance theory through the philosopher Henri Bergson's writings on disorder and the art practice of Janez Janša. When the future is considered as an unknown guaranteed, it becomes possible to invent life in the same way that art is created.
\end{abstract}

\title{
Keywords
}

Future, Failure, Bergson, Janez Janša, Time-specificity, Life/Art. 